\title{
FACTORS INFLUENCING ACADEMIC PERFORMANCE OF THE STUDENTS AT UNIVERSITY LEVEL EXAM: A LITERATURE REVIEW
}

\author{
Radheshyam H. Gajghat ${ }^{1}$, Chandrahas C. Handa ${ }^{2}$, Rakesh L. Himte ${ }^{3}$ \\ ${ }^{I}$ Ph.D. Research Scholar, Department of Mechanical Engineering, K.D.K. Collage of Engineering and Technology, \\ Nagpur, Maharashtra, India \\ ${ }^{2}$ Professor, Department of Mechanical Engineering, K.D.K. Collage of Engineering and Technology, Nagpur, \\ Maharashtra, India \\ ${ }^{3}$ Professor, Department of Mechanical Engineering, Priyadarshini Institute of Engineering and Technology, Nagpur, \\ Maharashtra, India
}

\begin{abstract}
It is a general perception that there are some personal characteristics, learning habits, previous academic background and college environmental factors which affect performance of the students at university level. These factors are directly or indirectly correlated with the students' performance. There are so many opinions about the impact of these factors. Some academicians think that personal characteristics, learning habits are more important whereas others argue that previous academic background and college environmental factors are more related with the students' performance. But there is substantial evidence that the views expressed by different stakeholders are not always consistent. Numbers of papers have been illustrated on the related topic and different multi-variable models have been developed to predict students' performance. This review article presents the results of some empirical investigations and illustrations of researches in the past. A new approach for tabulation of review papers is presented here which will ease and help the future researchers in their work.
\end{abstract}

Keywords: University students' performance, Independent factors, Dependent factors, Analysis tools

\section{INTRODUCTION}

The country has seen the quantitative growth of engineering institutions at diploma, degree and postgraduate level during last decade, mostly a phenomenal growth in number of engineering students. This has created opportunity, for $12^{\text {th }}$ Class students with lower scores to take admission to engineering courses, there by affecting the results. The poor result has also adversely affected the placement. [1]

As such now result of students is the highest concern of engineering education system. There are certain parameters which have significant impact on the performance and results of students like family background, personal characteristics, high school academic background, institutional environment etc. The previous studies proved that students' university results can be improved by predicting the influencing factors which affect their academic performance. Already there are so many models which have been developed to predict student success and failure at the university level. Most of the studies are focused on students' performance in the foreign universities, which may not be suitable for Indian universities due to the differences in their academic, social and cultural environment. So there is need to develop such a model which will be more suitable for the students of Indian universities. [2]
In most of the models semester/cumulative grade point average (SGPA/CGPA) and success/failure in the university examination has been taken as the dependent variable. Preschooling background, family background, personal characteristics, college environment and learning habits, and many more are considered as independent factors for predicting the students' performance at university level. In this review work, a number of papers in the related area have been studied which showed a good correlation between performance of students of different courses with a number of academic and non-academic factors.

\section{OBJECTIVE OF THE STUDY}

The objective of the study was to identify the important and significant factors which influence the students' performance in university examination. Important dependent factors also known as performing factors were identified from the previous literature. There were number of statistical tools used to predict and authenticate the relevance of the factors. Further the independent and dependent factors will be correlated to predict the performance of the students at university level.

\section{LITERATURE REVIEW}

In mathematical modelling and statistical modelling, there are dependent and independent variables. The models 
investigate how the former depend on the latter. The dependent variables represent the output or outcome whose variation is being studied. The independent variables represent inputs or causes, i.e. potential reasons for variation. Models test or explain the effects that the independent variables have on the dependent variables.

\subsection{Independent Factors}

There are so many independent factors which affect the students' performance in their university examination. These factors include pre-schooling background, family background, personal characteristics, college environment and learning habits etc. These factors may be broadly classified into academic and non-academic factors. Some of the previous research works related with the students' performance are discussed here.

In the recent research, Muhdin Muhammed Hussen [3] found university entrance exam score, family financial situation, sleeping time and study habit as the significant factors which affect students' academic performance. The investigation carried out by S. P. Singh et al. [4] revealed that there was a positive and statistically significant impact of learning facilities, communication skills and proper guidance from parents on student academic performance. An instrument was developed by Rita Kizito et al. [5] to identify and examine factors affecting student performance. In this analysis, workload found as the factor which having the greatest impact on student's performance, followed by the matriculation examination score. The interruption of electricity supply, overcrowded lecture rooms, unfavourable learning environment were found significant factors in the study of Emmanuel Adjei Frimpong et al. [6], which affect students' performance.

Mulugeta Tesfay and Dawit Zekiros [7] investigated that tension, college distance and harassment have statistically significant and adverse impacts on student performance whereas parents' academic level and students monthly fund received have positive statistically significant effects. In the study of Lucky Sibanda et al. [8] regular study, regular attendance and assignment completion were found highly influential factors for success and lack of effort, lack of dedication and commitment, not doing assignments were found highly ranked factors for failure. Justice Enu et al. [9] revealed that inadequate teaching, learning materials, selfmotivation and lecturer method of instruction were some of the factors which affect students' performance. Sarah M.S. Shathele, Anitha Oommen [10] investigated that facility available for study, family support, and awareness about the course had positive influence whereas anxiety, stress and lack of sleep had negative influence. Raheela Asif et al. [11] developed a model to predict the graduation performance in 4th year at university using only pre-university marks and marks of 1st and 2nd year courses. Andrew Lepp et al. [12] investigated that cell phone use/texting was negatively related to GPA and positively related to anxiety.
In the study H. Esin Erdem [13] found a significant relationship between students' achievement and factors such as preparatory school attendance, high school graduated from, father's education level, and class attendance. The results of the survey conducted by Maryam Mehri et al. [14] investigated that there was a meaningful relationship between career interest, mental health, aptitude, happiness and academic performance. The findings of the study carried out by Trevor G. Bennett \& Simon M.Yalams [15] showed that there was a positive and significant relationship between students' attendance, participation and performance in the class. Shoukat Ali et al. [16] investigated that age, father/guardian social economic status and daily study hours significantly contributed the academic performance of graduate students. Ahmed Abdi Aden et al. [17] found a moderate positive relationship between student attendance and academic performance in their study. Nadeem Talib and Sujit S. Sansgiry [18] identified that academic and test competence, time management, and test anxiety were significantly related to student's academic performance. The study carried out by Manju Chutia [19] showed that the relationship between Teachers' Job satisfaction and the academic performance of the students was high. As per the study conducted by Irfan Mushtaq \& Shabana Nawaz Khan [20], the communication, learning facilities and proper guidance showed the positive impact and the family stress showed the negative impact on the student performance.

R. R. Kabra \& R. S. Bichkar [1] have generated the model to predict the students' performance. The most important attribute in predicting student's performance was found to be HSCCET. The results of the study conducted by M.S. Mansour Garkaz et al. [21] found that gender, type of diploma, interest and employment status were significantly related to the academic performance. The most important findings of the research carried out by Mucella Ulug et al. [22] evidenced that teachers' positive attitudes have positively influence students' personality as well as their life performances. Zuhaina Zakaria et al. [23] conducted a survey which showed that environmental factors as well as gender have an impact on a students' academic performance. The salient findings of this pilot study were that female students that were given college accommodations perform better than students staying in private accommodations. Saima Rasul and Qadir Bukhsh [24] found that (i) at university level most of the psychological, physical, socioeconomic and educational factors affected their performance in examination (ii) change in pattern of question papers near examination affect student's performance (iii) unfair means in examination affect their performance (iv) Lack of proper guidance affect their performance in examination. Muhammad Amjad Saleem and Muhammad Imran Qureshi [25] have categorized all these factors into academic factors, personal factors, socio economic factors and co-curriculum and guidance. Impact of academic factors, personal factors, and socio economic factors on CGPA using Regression Analysis was found significant. Muhammad Daniyal et al. [26] found the eight factors that can influence the student's performance which were family income, father education, mother education, size of family, motivation of parents, 
involvement in co-curricular activities, regularity of teachers and interest in the subject developed by concerned teacher.

The outcome of the analysis carried out by Abdullah ALMutairi [27] revealed that the grade point average (GPA) of the student was affected by age, score of the high school and nationality. In addition, the result revealed that younger students perform better than mature students and nonnational students perform better than national student. The results further revealed that significant gender differences exists, female students perform better than male counterparts in line with a significant number of previous empirical studies. The study conducted by Hasan Afzal et al. [28] found strong, positive and mutually causal relationship between students' motivation and students' academic performance. Prima Vitasari et al. [29] observed that there was a significant correlation of high level anxiety and low academic performance among engineering students.

May Selim and S Al-Zarooni [30] found the secondary school grades almost correlate with the students' GPA. Also they noticed that the average GPA of the engineering students reduces with time from entry to the college to graduation. The investigation carried out by LP Steenkamp et al. [31] indicate that poor class attendance, inadequate preparation, insufficient time and a lack of English tuition were the main factors responsible for poor performance. The study conducted by Aboma Olani [32] showed that students' pre-college academic performances were strong predictors of GPA at university level. The results of the study conducted by Sarath A. Nonis et al. [33] suggested that nonability variables like motivation and study time significantly interact with ability to influence academic performance. Contrary to popular belief, the amount of time spent studying or at work had no direct influence on academic performance. The evidence of the study conducted by Daniel R. Marburger [34] suggests that an enforced mandatory attendance policy significantly reduces absenteeism and improves exam performance.

Brian F. French [35] included both cognitive and noncognitive variables in his study. Cognitive variables included high school rank, SAT scores, and university CGPA. Non-cognitive factors included academic motivation and institutional integration. Consistent with previous research, student pre-college variables, SATMath and HS rank, were significant predictors of GPA. Results of the study carried out by Tarek Abdel-Salam et al. [36] show a weak relationship between SAT scores and college performance. High school GPA was a relatively more reliable predictor of college level performance and success. Dennis, Jessica M. et al. [37] conducted a longitudinal study of 100 ethnic minority first-generation college students. In this study, personal/career-related motivation to attend college was a positive predictor and lack of peer support was a negative predictor. Guili Zhang et al. [38], in his study, found that High school GPA, gender, ethnicity, quantitative SAT scores, verbal SAT scores, and citizenship had significant impact on graduation.

Table-1: Summary of Significant Independent Factors found in Previous Research

\begin{tabular}{|c|c|c|c|c|c|}
\hline SN & $\begin{array}{l}\text { Significant Independent } \\
\text { Factors }\end{array}$ & References & $\mathbf{S N}$ & $\begin{array}{l}\text { Significant Independent } \\
\text { Factors }\end{array}$ & References \\
\hline 1 & Financial Condition & {$[3],[7],[16],[25],[26]$} & 25 & Dedication \& Commitment & [8] \\
\hline 2 & $\begin{array}{l}\text { Living Location/ Location } \\
\text { of School }\end{array}$ & {$[2],[13],[23],[39]$} & 26 & Family size & [26] \\
\hline 3 & Parents' Education & [7], [13], [20], [26] & 27 & $\begin{array}{l}\text { Maths in 12th class/SAT } \\
\text { Math }\end{array}$ & [35], [36] \\
\hline 4 & Time Management Skill & {$[18]$} & 28 & High school score/HSGPA & $\begin{array}{l}{[5],[30],[36],[38],} \\
{[40],[41]}\end{array}$ \\
\hline 5 & Self-motivation & $\begin{array}{llll}{[9],} & {[26],} & {[28],} & {[37],} \\
{[42],} & {[43]}\end{array}$ & 29 & HS Rank & [35] \\
\hline 6 & Self-discipline & {$[42]$} & 30 & Entrance Exam & {$[1],[3]$} \\
\hline 7 & $\begin{array}{l}\text { Desire to learn/ Acquire } \\
\text { more knowledge }\end{array}$ & {$[42]$} & 31 & $\begin{array}{l}\text { Prior knowledge of subject/ } \\
\text { course awareness }\end{array}$ & {$[10],[31]$} \\
\hline 8 & Efforts/Hardworking & {$[8]$} & 32 & Academic competency & {$[18],[25],[32]$} \\
\hline 9 & $\begin{array}{l}\text { Accommodation during } \\
\text { study }\end{array}$ & [23] & 33 & $\begin{array}{l}\text { Active participation in class } \\
\text { discussion }\end{array}$ & {$[2],[15]$} \\
\hline 10 & $\begin{array}{l}\begin{array}{l}\text { Excessive use of cell } \\
\text { phones/internet }\end{array} \\
\end{array}$ & {$[12]$} & 34 & Teaching quality & [9], [23] \\
\hline 11 & Career goal/interest & {$[14]$} & 35 & $\begin{array}{ll}\begin{array}{l}\text { Learning } \\
\text { environment }\end{array} & \text { support/ } \\
\end{array}$ & [4], [9], [10], [20] \\
\hline 12 & Interest in the course & [21], [26], [42] & 36 & Teacher's support/attitude & {$[22]$} \\
\hline 13 & Extra curriculum activities & {$[26]$} & 37 & $\begin{array}{lll}\begin{array}{l}\text { Faculty } \\
\text { interaction }\end{array} & \& \quad \text { Student } \\
\end{array}$ & [44] \\
\hline 14 & Gender & {$[2],[21],[23],[27],[38]$} & 38 & Class Attendance & $\begin{array}{l}{[2],[8],[13],[15],} \\
{[17],[31],[34],[41],}\end{array}$ \\
\hline
\end{tabular}




\begin{tabular}{|l|l|l|l|l|l|}
\hline & & & & & {$[45],[46]$} \\
\hline 15 & Ethnicity/caste & {$[38]$} & 39 & Teachers' job satisfaction & {$[19]$} \\
\hline 16 & Age & {$[16],[38]$} & 40 & Peer support & {$[37]$} \\
\hline 17 & Text Anxiety & {$[10],[12],[18],[29]$} & 41 & College distance & {$[7]$} \\
\hline 18 & Sleep time & {$[3],[10]$} & 42 & Harassment & {$[7]$} \\
\hline 19 & Mental health & {$[14]$} & 43 & Overcrowded lecture room & {$[6]$} \\
\hline 20 & Happiness & {$[14]$} & 44 & Regularity of Teacher & {$[26]$} \\
\hline 21 & Stress/Tension & {$[7],[10],[20]$} & 45 & $\begin{array}{l}\text { Written communication } \\
\text { skill in English }\end{array}$ & {$[2],[4],[20],[31]$} \\
\hline 22 & Guidance from parents & {$[4],[20]$} & 46 & $\begin{array}{l}\text { Sincere Preparation of } \\
\text { Class Notes/ Notebook }\end{array}$ & {$[31],[42]$,} \\
\hline 23 & Family support & {$[10]$} & 47 & Study habits & {$[3],[16]$} \\
\hline 24 & Mother's age & {$[20]$} & 48 & Assignment completion & {$[8]$} \\
\hline
\end{tabular}

William J. Fraser and Roy Killen [42] investigated the different perceptions of first-year students, senior students and lecturers and identified numerous important similarities and inconsistencies. Self-motivation and self-discipline has been given $1^{\text {st }}$ and $2^{\text {nd }}$ ranking for success items by lecturers and senior students both but there was significant difference for $3^{\text {rd }}$ ranking. Timely and regular examination preparation and interest in the course was given $3^{\text {rd }}$ ranking by lecturers and senior students respectively. Similarly for failure items, inadequate or poor exam preparation, lack of self-discipline and lack of self-motivation was given $1^{\text {st }}, 2^{\text {nd }}$ and $3^{\text {rd }}$ ranking by lectures respectively. But there was significant difference in mean ratings between lecturers and senior students. Boring presentations by lecturers, unclear criteria and lecturers' expectations of assignments, and lack of selfmotivation were given $1^{\text {st }}, 2^{\text {nd }}$ and $3^{\text {rd }}$ ranking by senior students respectively. Brian F. French et al. [44] examined a model of student success and persistence at two levels: university and engineering major. Grade point average was significantly related to enrolment in both the university and engineering major. Increased levels of student interactions were significantly related to continued enrolment in engineering. Joan R. Rodgers and John L. Rodgers [45] found strong support for the proposition that class attendance has a significant effect on academic performance. Siu-Man Raymond Ting [47] used Scholastic Aptitude Test (verbal, mathematics, and total) scores and the NonCognitive Questionnaire (which include eight psycho-social variables) for predicting GPA of engineering students. SAT total score was found the most effective single variable.

R.C. Jiloha \& Jugal Kishore [48] observed statistically significant differences among general, SC and ST medical students when their data regarding schooling, family income, parents' education and occupation and academic performance were compared. More failure in SC \& ST groups is attributable to their poor, social, economic and educational environment. Glenda Anthony [43] found motivation the most influential factor related to levels of success. Stephen Devadoss and John Foltz [41] studied several distinguished factors that influence attendance and grades are motivation, prior grade point average (GPA), self-financing by students, hours worked on jobs, quality of teaching, and nature of class lectures. This study also provided strong empirical evidence of the positive influence of class attendance on student performance. The results of the study carried out by Garey C. Durden and Larry V. Ellis [46] indicate that attendance does matter for academic achievement. The evidence suggested that the typical student was not adversely affected by a few absences, but excessive absenteeism was associated strongly with poor academic performance. Richard M. Felder et al. [49] observed the differences in academic performances between students from rural and small town backgrounds and students from urban and suburban backgrounds, with the urban students doing better on almost every measure investigated.

Table-2: Summary of Important Dependent Factors found in Previous Research

\begin{tabular}{|c|c|c|}
\hline SN & $\begin{array}{l}\text { Important } \\
\text { Dependent Factors }\end{array}$ & References \\
\hline 1 & $\begin{array}{l}\text { Semester/Cumulative } \\
\text { Grade Point Average } \\
\text { (SGPA/CGPA) }\end{array}$ & $\begin{array}{l}{[2],[3],[7],[12],[13],[14],} \\
{[15],[16],[18],[20],} \\
{[25],[23],[27],[28],} \\
{[30],[32],[33],[34],} \\
{[36],[37],[39],[40],} \\
{[441],} \\
{[44],[47],[49],[50],} \\
{[52],[53],[54],[55],} \\
{[56],}\end{array}$ \\
\hline 2 & Success/Failure & $\begin{array}{l}{[1],[8],[24],[31],[39],[61],} \\
{[62],,[63]}\end{array}$ \\
\hline 3 & $\begin{array}{l}\text { Relative Retention } \\
\text { Rate }\end{array}$ & {$[35],[64],[65]$} \\
\hline 4 & Time to Graduation & {$[38]$} \\
\hline 5 & $\begin{array}{l}\text { Marks Obtained in } \\
\text { End Semester Exam }\end{array}$ & $\begin{array}{l}{[16],[45],[61],[66],[67],} \\
{[68]}\end{array}$ \\
\hline
\end{tabular}

\subsection{Dependent Factors}

In most of the previous researches, as shown in Table-2, semester/cumulative grade point average (SGPA/CGPA) and success/ failure in the university examination has been taken as dependent variables for the prediction students' performance at university level. Other dependent variables 
considered were relative retention rate, time to graduation, marks obtained in end semester examination.

\subsection{Analysis Techniques and Methods}

These research studies result in a large volume of raw data which must be suitably filtered so that the related conclusion can be made easily and can be used for further analysis. There are so many analysis techniques which are used to calculate certain indices or measures along with searching pattern of relationship that exist among the data groups. The collected raw data or numerical description of facts is known as statistics. There are two major areas of statistics viz., descriptive statistics and inferential statistics. Descriptive statistics concern the development of certain indices from the raw data, whereas inferential statistics concern with the process of generalisation. Inferential statistics are also known as sampling statistics which are mainly concerned with estimating the values of unknown parameters of the population and testing of hypotheses for drawing interferences. [69]

The important statistical measures, that were used by the researches to summarise the research data, are measures of central tendency, measures of dispersion, measures of asymmetry (skewness), measure of relationship (regression and correlation analysis) and other measures. Table- 3 shows some of the important traditional and advanced analysis techniques which were used in previous research.

Table-3: Summary of Analysis Techniques and Methods used in Previous Research

\begin{tabular}{|c|c|c|c|c|c|}
\hline $\begin{array}{l}\mathbf{S} \\
\mathbf{N}\end{array}$ & $\begin{array}{l}\text { Analysis } \text { Techniques } \\
\text { Used }\end{array}$ & References & SN & $\begin{array}{l}\text { Analysis Techniques } \\
\text { Used }\end{array}$ & References \\
\hline 1 & ANOVA, MANOVA & $\begin{array}{l}{[4],[5],[20],[24],[28],} \\
{[31],[48],[54],[55],} \\
{[70],[71],[72]}\end{array}$ & 14 & ANN & $\begin{array}{llll}{[51],} & {[56],} & {[59],} & {[67],} \\
{[73]} & & \end{array}$ \\
\hline 2 & Chi-square test & 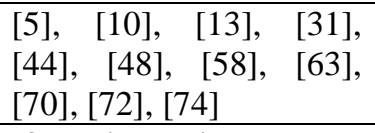 & 15 & Path analysis & {$[12],[44]$} \\
\hline 3 & Fisher's exact test & [39], [49], [74] & 16 & $\begin{array}{l}\text { Generalised squared multi } \\
\text { correlation }\end{array}$ & [44] \\
\hline 4 & Pearson correlation & 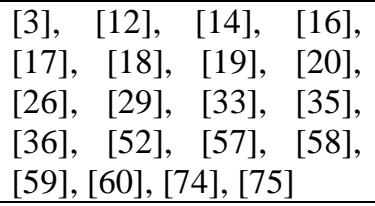 & 17 & $\begin{array}{l}\text { Ordinary least square } \\
\text { estimation of regression, } \\
\text { OLS }\end{array}$ & {$[2],[38],[45],[46]$} \\
\hline 5 & T-test & $\begin{array}{l}\text { [3], [5], [21], [34], [37], } \\
{[39],[41],[44],[49],} \\
{[54],[60],[76],[72]}\end{array}$ & 18 & $\begin{array}{l}\text { Generalised linear model, } \\
\text { GLM }\end{array}$ & [53] \\
\hline 6 & $\begin{array}{l}\text { Multiple linear } \\
\text { regression }\end{array}$ & 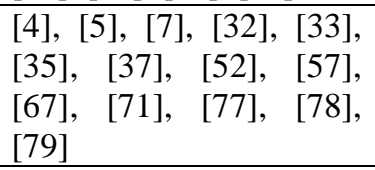 & 19 & Multinomial logit analysis & [40] \\
\hline 7 & $\begin{array}{l}\text { Wilcoxin's ranksum test } \\
\text { / Mann-Whiteny }\end{array}$ & [39], [43], [49], [64] & 20 & $\begin{array}{ll}\begin{array}{l}\text { Stepwise } \\
\text { analysis }\end{array} & \text { discriminate } \\
\end{array}$ & [18], [61], [71] \\
\hline 8 & Cramer's V score & [70] & 21 & Data mining & {$[11],[80]$} \\
\hline 9 & Logistic regression & $\begin{array}{llll}{[35],} & {[38],} & {[61],} & {[63],} \\
{[64],} & {[77],} & {[79],} & {[81],} \\
{[82]} & & & \\
\end{array}$ & 22 & Graphical method & {$[22],[23]$} \\
\hline $\begin{array}{l}1 \\
0\end{array}$ & $\begin{array}{l}\text { Simple/Stepwise linear } \\
\text { regression }\end{array}$ & $\begin{array}{llll}{[14],} & {[16],} & {[20],} & {[25],} \\
{[28],} & {[45],} & {[47],} & {[50],} \\
{[55],} & {[60],} & {[61],} & {[64],} \\
{[66],} & {[81],[79]}\end{array}$ & 23 & Z-test & [24] \\
\hline $\begin{array}{l}1 \\
1 \\
\end{array}$ & $\begin{array}{ll}\text { Explolary } & \text { factor } \\
\text { analysis } & \\
\end{array}$ & {$[5],[55],[72],[83]$} & 24 & Cross Tabulation & [60] \\
\hline $\begin{array}{l}1 \\
2\end{array}$ & Descriptive analysis & $\begin{array}{l}{[4],[6],[7],[8],[9],} \\
{[12],[15],[16],[18],} \\
{[19],[20],[24],[31],} \\
{[70],[72],[76]}\end{array}$ & 25 & Average weighted mean & [84] \\
\hline $\begin{array}{l}1 \\
3 \\
\end{array}$ & Decision tree algorithm & {$[1],[56],[85]$} & & & \\
\hline
\end{tabular}




\section{CONCLUSION}

Based on the critical review of 85 papers, articles, books related to the topic of the review paper the following conclusion can be drawn.

1. There is a defined effect of number of independent factors on the performance of students.

2. About 48 independent factors and 5 dependent factors were cited in the paper under considerations.

3. The review gives the global summary as the different geographical areas were considered by different researchers.

4. In majority of papers questionnaire method was used for collection of data.

5. 25 different types analyses techniques/test were used by the researches under references.

Various computational tools and softwares like SPSS, SYSTET, MATLAB, MINITAB, EXCEL etc. were used for computational analysis of the data.

This review paper would help the future researchers working in this area to have categorized insight of the researches by the researchers during 1995-2017.

\section{REFERENCES}

[1] R. Kabra and R. Bichkar, "Performance prediction of engineering students using decision trees," International Journal of Computer Applications, vol. 36, no. 11, 2011.

[2] N. Harb and A. El-Shaarawi, "Factors Affecting Students' Performance," 2006.

[3] M. H. Muhdin, "Determinants of Economics Students' academic performance: A case study of Jimma University, Ethiopia," International Journal of Scientific and Research Publications, vol. 6(1), pp. 566-571, 2016.

[4] S. P. Singh, S. Malik and P. Singh, "Factors Affecting Academic Performance of Students," Paripex - Indian Journal of Research, vol. 5(4), pp. 176-178, 2016.

[5] R. Kizito, J. Munyakazi and C. Basuayi, "Factors affecting student success in a first-year mathematics course: a South African experience," International Journal of Mathematical Education in Science and Technology, vol. 47, no. 1, pp. 100-119, 2016.

[6] E. A. Frimpong, G. A. Agyeman and F. F. Ofosu, "Institutional Factors Affecting the Academic Performance of Polytechnic Students in Ghana," International Journal of Humanities $1 \&$ Social Science Studies, vol. 2(5), pp. 102-109, 2016.

[7] M. Tesfay and D. Zekiros, "Factors Affecting Academic Performance of Female University Students," International Journal of Current Research, vol. 7(3), pp. 14139-14152, 2015.

[8] L. Sibanda, C. G. Iwu and O. H. Benedict, "Factors influencing academic performance of university students," Demography and Social Economy, vol. 24, no. 2, pp. 103-115, 2015.

[9] J. A. O. K. Enu and D. Nkum, "Factors Influencing Students' Mathematics Performance in Some
Selected Colleges of Education in Ghana," International Journal of Education Learning and Development, vol. 3(3), pp. 68-74, 2015.

[10] S. M. Shathele and A. Oommen, "Factors influencing the academic performance of the female medical students in preclinical and clinical years," Journal of Medicine and Medical Sciences, vol. 6, no. 6, pp. 109-114, 2015.

[11] R. Asif, A. Merceron and M. K. Pathan, "Predicting student academic performance at degree level: a case study," International Journal of Intelligent Systems and Applications, vol. 7, no. 1, p. 49, 2014.

[12] A. Lepp, J. E. Barkley and A. C. Karpinski, "The relationship between cell phone use, academic performance, anxiety, and satisfaction with life in college students," Computers in Human Behavior, vol. 31, pp. 343-350, 2014.

[13] H. E. Erdem, "A Cross-Sectional Survey in Progress on Factors Affecting Students' Academic Performance at a Turkish University," ProcediaSocial and Behavioral Sciences, vol. 70, pp. 691-695, 2013.

[14] M. Mehri, F. Rezaei and M. Abedi, "A social work study on the effect of personal characteristics on academic performance," Management Science Letters, vol. 3, no. 4, pp. 1119-1124, 2013.

[15] T. G. Bennett and S. M. Yalams, "Correlates of students' attendance to class, participation and performances in engineering modules," in Global Engineering Education Conference (EDUCON), 2013 IEEE, 2013.

[16] S. Ali, Z. Haider, F. Munir, H. Khan and A. Ahmed, "Factors contributing to the students academic performance: A case study of Islamia University SubCampus," American journal of educational research, vol. 1, no. 8, pp. 283-289, 2013.

[17] A. A. Aden, Z. A. Yahye and A. M. Dahir, "The Effect of Student's Attendance on Academic Performance: A Case Study at Simad University Mogadishu," Academic Research International, vol. 4, no. 6, p. 409, 2013.

[18] N. Talib and S. S. Sansgiry, "Determinants of academic performance of university students," Pakistan Journal of Psychological Research, vol. 27, no. 2, p. 265, 2012.

[19] M. Chutia, "Teachers' job satisfaction in degree colleges of greater Guwahati and its impact on students' academic performance," Golden Research Thoughts, vol. 2(6), 2012.

[20] S. N. K. Mushtaq and others, "Factors affecting students' academic performance," Global Journal of Management and Business Research, vol. 12, no. 9, 2012.

[21] M. Garkaz, B. Banimahd and H. Esmaeili, "Factors affecting accounting students' performance: the case of Students at the islamic azad university," ProcediaSocial and Behavioral Sciences, vol. 29, pp. 122-128, 2011.

[22] M. Ulug, M. S. Ozden and A. Eryilmaz, "The effects of teachers' attitudes on students' personality and 
performance," Procedia-Social and Behavioral Sciences, vol. 30, pp. 738-742, 2011.

[23] Z. Zakaria, R. A. Kassim, A. Mohamad and N. Buniyamin, "The impact of environment on engineering students' academic performance: A pilot study," in Engineering Education (ICEED), 2011 3rd International Congress, 2011.

[24] S. Rasul and Q. Bukhsh, "A study of factors affecting students' performance in examination at university level," Procedia-Social and Behavioral Sciences, vol. 15, pp. 2042-2047, 2011.

[25] M. A. Saleem and M. I. Qureshi, "Credentials and Examination of the Factors Affecting the Students' Academic Achievement in Higher Education (A Case Study of Universities in Public \& Private Sector at D.I. Khan)," Gomal University Journal of Research, vol. 27, no. 2, pp. 74-80, 2011.

[26] M. Daniyal, T. Nawaz, M. Aleem and A. Hassan, "The Factors Affecting the Students'performance: A Case Study of Islamia University of Bahawalpur, Pakistan," African Journal of Education and Technology, vol. 1, no. 2, pp. 45-51, 2011.

[27] A. M. Abdullah, "Factors affecting business students' performance in Arab Open University: The case of Kuwait," International Journal of Business and Management, vol. 6, no. 5, p. 146, 2011.

[28] H. Afzal, I. Ali, M. A. Khan and K. Hamid, "A study of University Students' Motivation and its relationship with their academic performance," International Journal of Business and Management, vol. 5, no. 4, p. 80, 2010.

[29] P. Vitasari, M. N. A. Wahab, A. Othman, T. Herawan and S. K. Sinnadurai, "The relationship between study anxiety and academic performance among engineering students," Procedia-Social and Behavioral Sciences, vol. 8, pp. 490-497, 2010.

[30] M. Selim and S. Al-Zarooni, "Do secondary school grades predict the performance of engineering students?," Australasian Journal of Engineering Education, vol. 15, no. 3, pp. 145-153, 2009.

[31] L. Steenkamp, R. Baard and B. Frick, "Factors influencing success in first-year accounting at a South African university: A comparison between lecturers' assumptions and students' perceptions," South African Journal of Accounting Research, vol. 23, no. 1, pp. 113-140, 2009.

[32] A. Olani, "Predicting first year university students' academic success," Electronic journal of research in educational psychology, vol. 7, no. 3, pp. 1053-1072, 2009.

[33] S. A. Nonis and G. I. Hudson, "Academic performance of college students: Influence of time spent studying and working," Journal of Education for Business, vol. 81, no. 3, pp. 151-159, 2006.

[34] D. R. Marburger, "Does mandatory attendance improve student performance?," The Journal of Economic Education, vol. 37, no. 2, pp. 148-155, 2006.

[35] B. F. French, J. C. Immekus and W. C. Oakes, "An examination of indicators of engineering students' success and persistence," Journal of Engineering Education, vol. 94, no. 4, pp. 419-425, 2005.

[36] T. Abdel-Salam, P. Kaufftnann and K. Williamson, "A case study: do high school GPA/SAT scores predict the performance of freshmen engineering students?," in Proceedings Frontiers in Education 35th Annual Conference, 2005.

[37] J. M. Dennis, J. S. Phinney and L. I. Chuateco, "The role of motivation, parental support, and peer support in the academic success of ethnic minority firstgeneration college students," Journal of College Student Development, vol. 46, no. 3, pp. 223-236, 2005.

[38] G. Zhang, T. J. Anderson, M. W. Ohland and B. R. Thorndyke, "Identifying Factors Influencing Engineering Student Graduation: A Longitudinal and Cross-Institutional Study," Journal of Engineering Education, vol. 93, no. 4, pp. 313-320, 2004.

[39] R. M. Felder, G. N. Felder, M. Mauney, C. E. Hamrin and E. J. Dietz, "A longitudinal study of engineering student performance and retention. III. Gender differences in student performance and attitudes," Journal of Engineering Education-Washington, vol. 84, pp. 151-164, 1995.

[40] K. H. Park and P. M. Kerr, "Determinants of academic performance: A multinomial logit approach," The Journal of Economic Education, vol. 21, no. 2, pp. 101-111, 1990.

[41] S. Devadoss and J. Foltz, "Evaluation of factors influencing student class attendance and performance," American Journal of Agricultural Economics, vol. 78, no. 3, pp. 499-507, 1996.

[42] W. J. Fraser and R. Killen, "Factors influencing academic success or failure of first-year and senior university students: do education students and lecturers perceive things differently?," South African Journal of Education, vol. 23, no. 4, pp. 254-263, 2003.

[43] G. Anthony, "Students' and Lecturers' Perceptions of Factors Influencing Students' Success in First-Year Undergraduate Mathematics Courses," MERGA 20 Aotearoa, pp. 58-64.

[44] B. F. French, J. C. Immekus and W. Oakes, "A structural model of engineering students success and persistence," in Frontiers in Education, 2003. FIE 2003 33rd Annual, 2003.

[45] J. R. Rodgers, J. L. Rodgers and others, "An investigation into the academic effectiveness of class attendance in an intermediate microeconomic theory class," Education Research and Perspectives, vol. 30, no. 1, p. 27, 2003.

[46] G. C. Durden and L. V. Ellis, "The effects of attendance on student learning in principles of economics," The American Economic Review, vol. 85, no. 2, pp. 343-346, 1995.

[47] S. Ting and R. Man, "Predicting academic success of first-year engineering students from standardized test scores and psychosocial variables," International Journal of Engineering Education, vol. 17, no. 1, pp. 75-80, 2001. 
[48] R. Jiloha and J. Kishore, "Socio-demography, personality profile and academic performance of various categories of medical students," Indian journal of psychiatry, vol. 40, no. 3, p. 231, 1998.

[49] R. Felder, P. Mohr, E. Dietz and L. Baker-Ward, "A longitudinal study of engineering student performance and retention. II. Differences between students from rural and urban backgrounds," Journal of Engineering Education, vol. 83, no. 3, pp. 209-217, 1994.

[50] L. W. Lackey, W. J. Lackey, H. M. Grady and M. T. Davis, "Efficacy of Using a Single, Non-Technical Variable to Predict the Academic Success of Freshmen Engineering Students," Journal of Engineering Education, vol. 92, no. 1, pp. 41-48, 2003.

[51] V. Oladokun, A. Adebanjo and O. Charles-Owaba, "Predicting students' academic performance using artificial neural network: A case study of an engineering course," The Pacific Journal of Science and Technology, vol. 9, no. 1, pp. 72-79, 2008.

[52] A. O. James and B. F. Tunde, "Cognitive Entry Characteristics and Semester Examination Scores as Correlates of College Students' Achievement in Mathematics," British Journal of Education, Society I\& Behavioural Science, vol. 3, no. 4, pp. 478-489, 2013.

[53] A. Luguterah and B. Apam, "Determinants of Academic Performance in Ghanaian Polytechnics," 2013.

[54] A. Ditcher and J. Tetley, "Factors influencing university students' academic success: what do students and academics think," in HERDSA Annual International Conference, Melbourne, 1999.

[55] C. P. Veenstra, E. L. Dey and G. D. Herrin, "Is Modeling of Freshman Engineering Success Different from Modeling of Non-Engineering Success?," Journal of Engineering Education, vol. 97, no. 4, pp. 467-479, 2008.

[56] P. Cheewaprakobkit, "Study of Factors Analysis Affecting Academic Achievement of Undergraduate Students in International Program," in Proceedings of the International MultiConference of Engineers and Computer Scientists, 2013.

[57] G. Kukreja and M. Aali, "The Determinants of Students' Performance in Introductory Accounting Courses: Evidence from Kingdom of Bahrain," Journal of Emerging Issues in Economics, Finance and Banking, vol. 1, no. 3, pp. 183-201, 2013.

[58] M. A. Choudhary, "Factors influencing engineering students' performance and their relationship with the student satisfaction with the teaching, learning as well as overall university experiences," in Information Technology Based Higher Education and Training (ITHET), 2012 International Conference, 2012.

[59] P. M. Arsad, N. Buniyamin, J. L. Ab Manan and N. Hamzah, "Proposed academic students' performance prediction model: A Malaysian case study," in Engineering Education (ICEED), 2011 3rd International Congress, 2011.
[60] Y. Mersha, A. Bishaw and F. Tegegne, "Factors affecting female students' academic achievement at Bahir Dar University," Journal of International Cooperation in Education, vol. 15, no. 3, pp. 135-148, 2013.

[61] M. Smith, L. Therry and J. Whale, "Developing a Model for Identifying Students at Risk of Failure in a First Year Accounting Unit.," Higher Education Studies, vol. 2, no. 4, pp. 91-102, 2012.

[62] J. O'Byrne, S. Britton, A. George, S. Franklin and A. Frey, Using academic predictors to identify first year science students at risk of failing, CAL-laborate International, 17 (1), 15-25, 2009.

[63] J. G. Soto and S. Anand, "Factors Influencing Academic Performance of Students Enrolled in a Lower Division Cell Biology Core Course.," Journal of the Scholarship of Teaching and Learning, vol. 9, no. 1, pp. 64-80, 2009.

[64] M. Besterfield-Sacre, C. J. Atman and L. J. Shuman, "Characteristics of freshman engineering students: Models for determining student attrition in engineering," Journal of Engineering Education, vol. 86, no. 2, pp. 139-149, 1997.

[65] J. Lin, P. Imbrie and K. J. Reid, "Student retention modelling: An evaluation of different methods and their impact on prediction results," Research in Engineering Education Sysmposium, pp. 1-6, 2009.

[66] S. Lee, M. C. Harrison, G. Pell and C. L. Robinson, "Predicting performance of first year engineering students and the importance of assessment tools therein," Engineering education, vol. 3, no. 1, pp. 4451, 2008.

[67] S. Huang and N. Fang, "Prediction of Students' Academic Performance in an Introductory Engineering Course," in 41st ASEE/IEEE Frontiers in Education Conference, October 12 - 15, 2011, 2011.

[68] J. Guardia, M. Freixa, M. Pero, J. Turbany, A. Cosculluela, M. Barrios and X. Rifa, "Factors related to the academic performance of students in the statistics course in psychology," Quality $1 \&$ Quantity, vol. 40, no. 4, pp. 661-674, 2006.

[69] C. Kothari, Research Methodology Methods and Techniques, New Age Internatinal (P) Ltd., Publishers, 2004.

[70] V. Mlambo, "An analysis of some factors affecting student academic performance in an introductory biochemistry course at the University of the West Indies," The Caribbean Teaching Scholar, vol. 1, no. 2, 2012.

[71] J. Burtner, "The use of discriminant analysis to investigate the influence of non-cognitive factors on engineering school persistence," Journal of Engineering Education, vol. 94, no. 3, p. 335, 2005.

[72] V. N. Kalbande and Dr. C. C. Handa, "Identification of Important Parameters \& Skills Required by Engineering Students in Campus Placement Process," International Journal of Engineering ResearchOnline, vol. 3, pp. 1-7, 2015. 
[73] V. N. Kalbande and Dr. C. C. Handa, "Predicting the Performance of Engineering Students in Campus Placement for IT Sector by Using ANN," International Journal of Research and Scientific Innovation, vol. 3, pp. 109-113, 2016.

[74] R. M. Felder, K. D. Forrest, L. Baker-Ward, E. J. Dietz and P. H. Mohr, "A longitudinal study of engineering student performance and retention: I. Success and failure in the introductory course," Journal of Engineering Education, vol. 82, no. 1, pp. 15-21, 1993.

[75] S. Rauchas, B. Rosman, G. Konidaris and I. Sanders, "Language performance at high school and success in first year computer science," in ACM SIGCSE Bulletin, 2006.

[76] B. Ayuba and N. Mohammed, "Investigating the Factors Affecting Performance of Business Management Students in Nigerian Universities," IOSR Journal of Business and Management, vol. 16(8), pp. 11-20, 2014.

[77] Q. Li, H. Swaminathan and J. Tang, "Development of a classification system for engineering student characteristics affecting college enrollment and retention," Journal of Engineering Education, vol. 98, no. 4, pp. 361-376, 2009.

[78] S. T. Hijazi and S. Naqvi, "Factors Affecting Students' performance.," Bangladesh e-Journal of Sociology, vol. 3, no. 1, 2006.

[79] V. N. Kalbande and Dr. C. C. Handa, "Developing a Model to Correlate Employability of Engineering Graduate with Employability Skill Sets in Campus Placement for IT Sector," Online International Interdisciplinary Research Journal, vol. 6, pp. 128138, 2016.

[80] E. P. I. Garcia and P. M. Mora, "Model prediction of academic performance for first year students," in Artificial Intelligence (MICAI), 2011 10th Mexican International Conference, 2011.

[81] M. N. R. Ayan and M. T. C. Garcia, "Prediction of university students' academic achievement by linear and logistic models," The Spanish journal of psychology, vol. 11, no. 01, pp. 275-288, 2008.

[82] V. N. Kalbande and Dr. C. C. Handa, "Developing a Model to Predict Employability of Engineering Students in Campus Placement for IT Sector," International Journal of Advance Research in Engineering, Science \& Technology, vol. 2, pp. 201 206, 2015.

[83] S. F. Mokhtar, Z. Md Yusof and M. Misiran, "Factors affecting students' performance in mathematics," Journal of Applied Sciences Research, vol. 8, no. 8, pp. 4133-4137, 2012.

[84] S. B. Alos, L. C. Caranto and J. J. T. David, "Factors affecting the academic performance of the student nurses of BSU," International Journal of Nursing Science, vol. 5, no. 2, pp. 60-65, 2015.

[85] F. Berhanu and A. Abera, "Students' Performance Prediction based on their Academic Record," International Journal of Computer Applications, vol. 131, no. 5, pp. 27-35, 2015.

\section{BIOGRAPHIES}

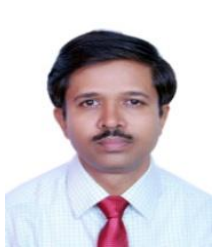

Radheshyam H. Gajghat is a Ph.D. Research Scholar at Department of Mechanical Engineering, KDK College of Engineering, RTM Nagpur University, Nagpur, Maharashtra, India. He obtained his BE (Prod.) from RTM Nagpur University, Maharashtra, Nagpur, India and MTech (Prod.) from MNNIT, Allahabad, Uttarpradesh, India.

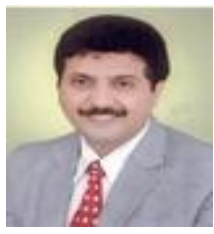

Dr. Chandrahas C. Handa is a Professor and Head of Department of Mechanical Engineering at KDK College of Engineering, RTM Nagpur University, Nagpur, Maharashtra, India. He obtained his $\mathrm{PhD}$ in Mechanical Engineering from RTM Nagpur University, Maharashtra, Nagpur, India. He has published and presented more than one hundred and fifty research papers in international and national journals/conferences.

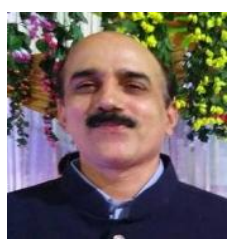

Dr. Rakesh L. Himte is a Professor and Head of Department of Mechanical Engineering at Priyadarshini Institute of Engineering and Technology, RTM Nagpur University, Maharashtra, Nagpur, India. He obtained his $\mathrm{PhD}$ in Mechanical Engineering from RTM Nagpur University, Maharashtra, Nagpur, India. He has published and presented more than fifty research papers in international and national journals/conferences 